\title{
PERTUMBUHAN DAN HASIL PAPRIKA (Capsicum annuum var- grossum) PADA BEBERAPA JENIS NAUNGAN
}

\section{THE GROWTH AND YIELD OF PAPRIKA ON DIFFERENT SHADES}

\author{
Stella M. T. Tulung dan Sofia Demmassabu*) \\ *Jurusan Budidaya Pertanian Fakultas Pertanian Unsrat Manado_95115
}

\begin{abstract}
The objective of this research is to detect the influence of shade kinds to the growth and yield of paprika and the suitable kinds of shades for paprika. Varieties Yolo Wonder was applied in this research and the research was located at Kakaskasen III, Kecamatan Tomohon Utara for four months. The research was carried on through Randomized Group Design by using three types of treatments and six replicates. The treatments were as follows: without shade, using transparent plastic shade and using stubble of paddy shade. Detected variable included: the height of the plant, leaf area, amount of the fruit, length, diametre and the weight of the fruit. The height of the plant measured every week since two weeks after planting and the leaf area was measured according to the height of the plant. The amount, lenght, diametre and the weight of the fruit measured during the harvest time. The result of the research shows that diffrerent kinds of shades brings different influence to the growth and yield of paprika and the research shows that the suitable shade for the growth and yield of paprika is transparent plastic shade.
\end{abstract}

Keyword: paprika, shade

\begin{abstract}
ABSTRAK
Tujuan dari penelitian ini ialah untuk mengetahui pengaruh beberapa jenis naungan terhadap pertumbuhan dan hasil Paprika serta mendapatkan jenis naungan yang paling sesuai untuk pertumbuhan dan hasil Paprika. Penelitian ini menggunakan Paprika varietas Yolo Wonder dan dilaksanakan di Kakaskasen III Kecamatan Tomohon Utara selama empat bulan. Penelitian menggunakan Rancangan Acak Kelompok dengan tiga perlakuan dan enam ulangan. Perlakuan meliputi : tanpa naungan, menggunakan naungan plastik transparan dan menggunakan naungan jerami padi. Variabel pengamatan meliputi: tinggi tanaman, luas daun, jumlah buah, panjang, diameter dan bobot buah. Tinggi tanaman diukur setiap minggu sekali dimulai pada saat tanaman berumur dua minggu setelah tanam, luas daun diukur bersamaan dengan tinggi tanaman. Jumlah buah, panjang buah, diameter buah dan bobot buah diukur pada saat panen. Hasil penelitian menunjukkan jenis naungan yang berbeda memberikan pengaruh yang berbeda terhadap pertumbuhan dan hasil Paprika. Jenis naungan yang paling sesuai untuk Paprika ialah plastik transparan.
\end{abstract}

Kata kunci Paprika, naungan

Eugenia Volume 17 No. 2 Agustus 2011 


\section{PENDAHULUAN}

Paprika (Capsicum annuum var-grossum) merupakan salah satu komoditi sayuran yang dimanfaatkan buahnya. Umumnya paprika dipakai untuk garnish (hiasan makanan) atau salad. Akan tetapi, paprika dapat juga dijadikan lauk pokok sebab paprika mengandung gizi yang cukup tinggi, karena pada setiap $100 \mathrm{~g}$ buah hijau segar mengandung protein $0,90 \mathrm{~g}$, lemak $0,30 \mathrm{~g}$, karbohidrat 4,40 g, vitamin A 22,00 IU, vitamin B1 $540,00 \mathrm{mg}$, vitamin C 160,00 mg (Prihantoro dan Indriani, 2000).

Walaupun paprika belum menjadi kebutuhan rutin sehari-hari, akan tetapi peluang pasar cukup menjanjikan karena konsumen tetap adalah hotel, pasar swalayan, dan perusahaan catering. Oleh karena itu, petani harus tetap membudidayakan paprika agar pasokan ke pasar tetap ada.

Masalah utama yang dihadapi dalam budidaya paprika di daerah tropis adalah intensitas cahaya yang tinggi, sedangkan tanaman paprika peka terhadap intensitas cahaya yang tinggi. Hal ini akan menyebabkan tanaman rusak oleh penyinaran yang kuat (Williams, Uzo dan Peregrine, 1993). Intensitas cahaya yang tinggi akan meningkatkan suhu daun. Suhu yang tinggi akan mempengaruhi efektivitas kerja enzim sehingga sintesis klorofil terhambat. Akibatnya proses fotosintesis terganggu sehingga pertumbuhan tanaman akan terhambat. Selain itu intensitas cahaya tinggi yang diterima tanaman dapat menyebabkan suhu daun meningkat, sehingga laju respirasi meningkat. Hal ini dapat menyebabkan tanaman akan kekurangan air, apabila penyerapan air dari dalam tanah tidak mampu mengimbangi. Apabila tanaman kekurangan air, pertumbuhan terhambat sehingga hasil rendah.

Salah satu cara yang dapat dilakukan untuk mengurangi penerimaan cahaya pada tanaman paprika adalah dengan penggunaan naungan. Alberta (2004) mengemukakan bahwa tanaman paprika merupakan salah satu komoditas penting yang dibudidayakan di bawah naungan. Bahan naungan yang dapat digunakan antara lain adalah plastik transparan atau jerami padi. Adapun model naungan yang dapat diterapkan dalam budidaya paprika ialah melengkung, horizontal maupun bentuk rumah (greenhouse) (Cahyono, 2007).

Hasil penelitian Asandhi dan Suryadi, 1984 didapatkan bahwa penggunaan naungan plastik transparan dapat meningkatkan bobot buah cabai besar sebesar 112,94\% (Anonimous, 1990). Sementara itu hasil penelitian Hanolo, Bakrie dan Thalib (1992) mendapatkan bahwa naungan plastik dapat meningkatkan pertumbuhan dan produksi tanaman paprika. Muhanda (2010) melaporkan bahwa budidaya paprika di Cisarua dengan menggunakan teknik hidroponik di bawah naungan plastik meningkatkan panen 2x lipat. Berdasarkan hal di atas maka dilakukan penelitian tentang pengaruh naungan terhadap pertumbuhan dan hasil paprika.

Penelitian ini bertujuan untuk mengetahui pengaruh beberapa jenis naungan terhadap pertumbuhan dan hasil paprika serta mendapatkan jenis naungan yang paling sesuai untuk pertumbuhan dan hasil paprika.

\section{METODE PENELITIAN}

Penelitian ini dilaksanakan di Kelurahan Kakaskasen III Kecamatan Tomohon Utara, selama 4 bulan. Bahan yang digunakan terdiri dari benih paprika var.Yolo Wonder, plastik transparan, jerami pada, pupuk kandang, dan pupuk N, P, K. Sedangkan alat yang digunakan berupa kotak semai, meteran, timbangan, tali, dan alat tulis menulis.

Penelitian ini dilakukan dengan menggunakan Rancangan Acak Kelompok (RAK) yang terdiri dari tiga perlakuan dan diulang sebanyak enam kali. Yang menjadi perlakuan adalah: $A=$ tanpa naungan, $B=$ naungan plastik transparan, dan $C=$ naungan jerami.

\section{Prosedur Kerja \\ Pesemaian}

Media untuk pesemaian terdiri dari campuran tanah dan pupuk kandang ayam dengan perbandingan 2 : 1. Sebelum dicampur, tanah diayak terlebih dahulu. Hasil ayakan tanah tersebut 
kemudian dicampurkan. Sebelum disemai, benih direndam dalam air hangat $\left(20^{\circ} \mathrm{C}\right)$ selama 4 jam kemudian dikering-anginkan. Setelah itu benih ditanam di kotak semai sedalam $0,5 \mathrm{~cm}$. Bibit siap ditanam setelah memiliki $4-5$ helai daun.

\section{Pengolahan Tanah}

Sementara bibit disemai, siapkan areal penanaman. Tanah digemburkan dan dibersihkan kemudian dibuat bedengan sebanyak 15 plot dengan ukuran tiap plot $3 \times 1,5$ meter. Tinggi bedengan $40 \mathrm{~cm}$, dengan jarak antar tiap plot 50 $\mathrm{cm}$.

\section{Pembuatan Naungan}

Pembuatan naungan dilakukan setelah pengolahan tanah. Naungan dibuat agak miring, atap bagian depan dibuat menghadap ke timur dan lebih tinggi dari atap bagian belakang. Naungan dipasang dengan panjang $3 \mathrm{~m}$ dan lebar $1,5 \mathrm{~m}$ serta tinggi naungan bagian depan yang menghadap ke timur $2 \mathrm{~m}$, dan bagian belakang 1,5 m. untuk naungan jerami padi, digunakan jerami padi sebanyak $10 \mathrm{~kg} /$ plot.

\section{Penanaman}

Penanaman dilakukan apabila bibit telah berumur 4 minggu dan telah memiliki 4 atau 5 helai daun. Pada setiap bedengan dibuat lubang dengan jarak tanam $50 \times 60 \mathrm{~cm}$. kemudian tiap lubang ditanami 1 bibit paprika. Tiap plot ditanami 18 tanaman paprika.

\section{Pemupukan}

Pemupukan dilakukan secara bertahap. Dimana, pupuk kandang diberikan pada saat pengolahan tanah dengan dosis 20 ton/ha (9kg/plot). Pupuk N, P, dan K diberikan secara bertahap yaitu: Pemupukan I, yaitu 10 hari setelah tanam dengan dosis: Urea $45 \mathrm{~g} / \mathrm{plot}, \mathrm{SP}-3618$ $\mathrm{g} /$ plot, dan $\mathrm{KCl} 31,5 \mathrm{~g} /$ plot. Pemupukan II, yaitu 30 hari setelah tanam dengan dosis: Urea 67,5 g/plot, SP-36 27 g/plot, dan KCl 45 g/plot. Pemupukan III, yaitu 45 hari setelah tanam dengan dosis: Urea $112,5 \mathrm{~g} /$ plot, SP-36 49,5 g/plot, dan KCl 85,5 g/plot.

\section{Pemeliharaan}

Pemeliharaan meliputi: penyiraman, pemangkasan, pengajiran, serta pemberantasan hama dan penyakit. Penyiraman dilakukan $2 x$ sehari (pagi dan sore) atau tergantung dengan kondisi cuaca. Pemangkasan dilakukan pada tunas yang keluar di ketiak daun mulai umur 3 MST, demikian pula dengan daun-daun yang terdapat pada bagian pangkal batang sampai pada percabangan utama dibuang pada 7 MST. Pengajiran dilakukan pada saat tanaman berumur 3 minggu. Pemberantasan hama dan penyakit dilakukan dengan menggunakan Decis dan Dithane-M45

\section{Variabel Pengamatan}

Variabel yang diamati dalam penelitian ini adalah: tinggi tanaman $(\mathrm{cm})$, luas daun $\left(\mathrm{cm}^{2}\right)$, jumlah buah, panjang buah $(\mathrm{cm})$, diameter buah (cm), dan bobot buah (gr). Variabel ini diukur dengan konsepsi pengukuran: 1) Pengukuran tinggi tanaman dilakukan seminggu sekali dan dimulai 2 minggu setelah tanam. Tinggi tanaman diukur dari pangkal batang sampai dengan pucuk tanaman. 2) Luas daun diukur dengan leaf area meter dilakukan seminggu sekali bersamaan dengan pengukuran tinggi tanaman. 3) Jumlah buah dihitung saat panen. 4) Panjang buah diukur dengan menggunakan mistar. 5) Diameter buah diukur dengan menggunakan rumus $d=2 . r$, dimana $r=$ jari-jari. Diukur saat panen. 6) Bobot buah diukur dengan menggunakan timbangan.

Kriteria panen adalah buah mudah lepas dari tangkainya, warna kulit buah hijau mengkilap. Panen dilakukan dengan interval +- seminggu sekali sebanyak 4 kali panenan.

\section{HASIL DAN PEMBAHASAN}

\section{Tinggi Tanaman}

Hasil analisis ragam menunjukkan bahwa perlakuan naungan berpengaruh nyata terhadap tinggi tanaman pada 3 MST - 11 MST sedangkan pada 2 MST perlakuan naungan belum berpengaruh terhadap tinggi tanaman. Rata-rata tinggi tanaman dapat dilihat pada tabel 1 . 
Tabel 1: Pengaruh Naungan terhadap Rata-rata Tinggi Tanaman Paprika (cm)

(Table 1. The Effect of Shade to The Average Height of Paprika (cm))

\begin{tabular}{|c|c|c|c|c|c|c|c|c|c|c|}
\hline \multirow[b]{2}{*}{ Perlakuan } & \multicolumn{10}{|c|}{ Rata-rata tinggi tanaman pada umur } \\
\hline & 2 & 3 & $\begin{array}{c}4 \\
\mathrm{MST}\end{array}$ & 5 & 6 & $\begin{array}{c}7 \\
S T\end{array}$ & 8 & $\begin{array}{c}9 \\
S T\end{array}$ & 10 & 11 \\
\hline $\begin{array}{l}\text { A. Tanpa } \\
\text { Naungan }\end{array}$ & 13,60 & $15,35 \mathrm{a}$ & $18,85 a$ & $22,01 a$ & $25,25 a$ & $29,50 a$ & $32,85 a$ & $34,86 a$ & $36,10 a$ & $37,22 \mathrm{a}$ \\
\hline $\begin{array}{l}\text { B. Naungan } \\
\text { Plastik } \\
\text { Transparan }\end{array}$ & 16,04 & $22,40 \mathrm{~b}$ & $27,85 b$ & $34,02 b$ & $34,48 b$ & $43,31 b$ & $45,85 b$ & $49,43 b$ & $48,41 b$ & $49,75 b$ \\
\hline $\begin{array}{l}\text { C. Naungan } \\
\text { Jerami Padi }\end{array}$ & 15,41 & $20,14 b$ & $24,82 b$ & $29,85 b$ & $35,35 b$ & $40,72 b$ & $41,45 b$ & $45,66 \mathrm{~b}$ & $46 \mathrm{~b}$ & $46,55 b$ \\
\hline BNT 5\% & & 4,44 & 4,70 & 5,13 & 6,01 & 7,30 & 6,36 & 6,77 & 7,12 & 5,60 \\
\hline
\end{tabular}

Ket : Angka yang diikuti huruf yang sama tidak berbeda nyata pada uji BNT 5\%

Tabel 2: Pengaruh Naungan terhadap Rata-rata Luas Daun Tanaman Paprika $\left(\mathrm{cm}^{2}\right)$

(Table 2. The Effect of Shade to the Average of Leaf Area $\left(\mathrm{cm}^{2}\right)$ )

\begin{tabular}{|c|c|c|c|c|c|c|c|c|c|c|}
\hline \multirow{2}{*}{$\begin{array}{l}\text { Waktu } \\
\text { pengamatan }\end{array}$} & \multicolumn{10}{|c|}{ Rata-rata tinggi tanaman pada umur } \\
\hline & \multirow{2}{*}{$\begin{array}{c}2 \\
\text { MST }\end{array}$} & \multirow{2}{*}{$\begin{array}{c}3 \\
\text { MST }\end{array}$} & \multirow{2}{*}{$\begin{array}{c}4 \\
\text { MST }\end{array}$} & \multirow{2}{*}{$\begin{array}{c}5 \\
\text { MST }\end{array}$} & \multirow{2}{*}{$\begin{array}{c}6 \\
\text { MST }\end{array}$} & \multirow{2}{*}{$\begin{array}{c}7 \\
\text { MST }\end{array}$} & \multirow{2}{*}{$\begin{array}{c}8 \\
\text { MST }\end{array}$} & \multirow{2}{*}{$\begin{array}{c}9 \\
\text { MST }\end{array}$} & \multirow{2}{*}{$\begin{array}{c}10 \\
\text { MST }\end{array}$} & \multirow{2}{*}{$\begin{array}{c}11 \\
\text { MST }\end{array}$} \\
\hline Perlakuan & & & & & & & & & & \\
\hline $\begin{array}{l}\text { A. Tanpa } \\
\text { Naungan } \\
\text { B. Naungan }\end{array}$ & 132,42 & $139,61 \mathrm{a}$ & $179,63 a$ & $226,17 a$ & $330,84 a$ & $376,77 a$ & $294,43 a$ & $383,02 a$ & $384,07 a$ & $384,61 a$ \\
\hline $\begin{array}{l}\text { Plastik } \\
\text { Transparan }\end{array}$ & $257,4 b$ & $343,32 b$ & $639,49 c$ & $696,14 \mathrm{c}$ & $810,02 \mathrm{c}$ & $914,57 \mathrm{c}$ & $806,27 c$ & $917,34 \mathrm{c}$ & $918,30 \mathrm{c}$ & $919,16 c$ \\
\hline $\begin{array}{l}\text { C. Naungan } \\
\text { Jerami Padi }\end{array}$ & $230,6 b$ & $361,45 b$ & $576,06 b$ & $619,81 b$ & $689,57 b$ & $836,91 b$ & $689,49 b$ & $842,17 b$ & $841,91 b$ & $842,39 b$ \\
\hline BNT 5\% & 61,52 & 60,75 & 49,72 & 48,25 & 60,25 & 49,11 & 61,21 & 52,12 & 51,95 & 52,15 \\
\hline
\end{tabular}

Ket : Angka yang diikuti huruf yang sama tidak berbeda nyata pada uji BNT 5\%

Rata-rata tinggi tanaman paprika pada umur 3 MST sampai 11 MST, menunjukkan bahwa perlakuan $A$ berbeda nyata dengan perlakuan $B$ dan C. Namun perlakuan B tidak berbeda nyata dengan perlakuan $\mathrm{C}$.

\section{Luas Daun}

Hasil analisis ragam menunjukkan bahwa penggunaan naungan berpengaruh nyata terhadap luas daun. Rata-rata luas daun dapat dilihat pada tabel 2.

Dari Tabel 2 didapatkan bahwa rata-rata luas dan daun pada umur 2 MST dan 3 MST, perlakuan A (tanpa naungan) berbeda nyata dengan perlakuan $B$ (naungan plastik transparan) dan perlakuan $C$ (naungan jerami padi), tetapi perlakuan $B$ belum berbeda nyata dengan perlakuan C. Rata-rata luas daun pada tanaman paprika pada umur 4 s.d 11 MST menghasilkan perbedaan nyata antara perlakuan $A, B$, dan $C$.

\section{Jumlah Buah}

Hasil analisis ragam menunjukkan bahwa penggunaan naungan berpengaruh nyata terhadap jumlah buah. Rata-rata jumlah buah paprika dapat dilihat pada Tabel 3.

Dari Tabel 3 didapatkan bahwa rata-rata jumlah buah menunjukkan perlakuan A (tanpa naungan), berbeda nyata dengan perlakuan $B$ (naungan plastik transparan), dan perlakuan $\mathrm{C}$ (naungan jerami padi). 
Tabel 3: Pengaruh Naungan terhadap Rata-rata Jumlah Buah Tanaman Paprika

(Table 3. The Effect of Shade to The Average of Amount of Fruit of Paprika)

\begin{tabular}{lc}
\hline \multicolumn{1}{c}{ Perlakuan } & Rata - Rata Jumlah Buah \\
\hline A. Tanpa Naungan & $1,31 \mathrm{a}$ \\
B. Naungan Plastik Transparan & $3,00 \mathrm{c}$ \\
C. Naungan Jerami Padi & $2,18 \mathrm{~b}$ \\
\hline
\end{tabular}

BNT $5 \%=0,22$

Ket : Angka yang diikuti huruf yang sama tidak berbeda nyata pada uji BNT 5\%

Tabel 4: Pengaruh Naungan terhadap Rata-rata Panjang Buah Paprika (cm)

(Table 4. The Effect of Shade to The Lenght of Fruit of Paprika (cm))

\begin{tabular}{lc}
\hline \multicolumn{1}{c}{ Perlakuan } & Rata - Rata Panjang Buah \\
\hline A. Tanpa Naungan & $6,08 \mathrm{a}$ \\
B. Naungan Plastik Transparan & $7,48 \mathrm{c}$ \\
C. Naungan Jerami Padi & $7,04 \mathrm{~b}$ \\
\hline BNT 5\% $=0,38$ &
\end{tabular}

Ket : Angka yang diikuti huruf yang sama tidak berbeda nyata pada uji BNT 5\%

\section{Panjang Buah}

Hasil analisis ragam menunjukkan bahwa penggunaan naungan berpengaruh nyata terhadap rata-rata panjang buah paprika. Rata-rata panjang buah paprika dapat dilihat pada Tabel 4.

Dari Tabel 4 didapatkan bahwa rata-rata panjang buah menunjukkan bahwa perlakuan $A$ (tanpa naungan), berbeda nyata dengan perlakuan $B$ (naungan plastik transparan), dan perlakuan $C$ (naungan jerami padi). Rata-rata panjang buah menunjukkan bahwa perlakuan $B$ menghasilkan buah terpanjang $(7,48 \mathrm{~cm})$ diikuti dengan perlakuan C $(7,04 \mathrm{~cm})$ dan paling pendek tanpa naungan $(6,08 \mathrm{~cm})$.

\section{Diameter Buah}

Hasil analisis ragam menunjukkan bahwa penggunaan naungan berpengaruh nyata terhadap diameter buah paprika. Rata-rata diameter buah paprika dapat dilihat pada Tabel 5 .

Dari Tabel 5 didapatkan bahwa rata-rata diameter buah menunjukkan bahwa perlakuan $\mathrm{A}$ (tanpa naungan), berbeda nyata dengan perlakuan B (naungan plastik transparan), dan perlakuan $C$ (naungan jerami padi). Rata-rata diameter buah menunjukkan bahwa perlakuan $B$ menghasilkan rata-rata diameter buah tertinggi $(7,63 \mathrm{~cm})$ diikuti dengan perlakuan $\mathrm{C}(6,96 \mathrm{~cm})$ dan yang menghasilkan diameter terendah adalah pelakuan A $(6,53 \mathrm{~cm})$.

\section{Bobot Buah}

Hasil analisis ragam menunjukkan bahwa penggunaan naungan berpengaruh nyata terhadap Bobot buah paprika. Rata-rata Bobot buah paprika dapat dilihat pada Tabel 6 .

Dari Tabel 6 didapatkan bahwa rata-rata diameter buah menunjukkan bahwa perlakuan $\mathrm{A}$ (tanpa naungan), berbeda nyata dengan perlakuan B (naungan plastik transparan), dan perlakuan $C$ (naungan jerami padi). Rata-rata bobot buah menunjukkan bahwa perlakuan $B$ menghasilkan rata-rata bobot buah tertinggi $(126,11 \mathrm{~g})$ diikuti dengan perlakuan $C(104,02 \mathrm{~g})$ dan yang menghasilkan diameter terendah adalah pelakuan A $(81,55 \mathrm{~g})$.

Hasil penelitian menunjukkan tinggi tanaman yang diberi naungan dan yang tidak terdapat perbedaan. Tanaman yang tumbuh tanpa naungan lebih pendek dari pada yang mendapat naungan. Tanaman yang diberi naungan juga memiliki luas'daun lebih besar dari pada tanpa naungan. Dari beberapa kali pengamatan, tanaman dengan naungan plastik transparan memiliki luas daun lebih besar dari pada tanaman yang ditanam di bawah naungan jerami. 
Tabel 5: Pengaruh Naungan terhadap Rata-rata Diameter Buah Paprika (cm)

(Table 5. The Effect of Shade to The Diametre of Fruit of Paprika $(\mathrm{cm})$ )

\begin{tabular}{llc}
\hline \multicolumn{1}{c}{ Perlakuan } & Rata - Rata Diameter Buah \\
\hline A. Tanpa Naungan & $6,53 \mathrm{a}$ \\
B. Naungan Plastik Transparan & $7,63 \mathrm{c}$ \\
C. Naungan Jerami Padi & $6,96 \mathrm{~b}$ \\
\hline
\end{tabular}

BNT $5 \%=0,38$

Ket : Angka yang diikuti huruf yang sama tidak berbeda nyata pada uji BNT 5\%

Tabel 6: Pengaruh Naungan terhadap Rata-rata Bobot Buah Paprika (g)

(Table 6. The Effect of Shade to The Average of Fresh Weight of Fruit of Paprika $(\mathrm{g})$ )

\begin{tabular}{llc}
\hline \multicolumn{1}{c}{ Perlakuan } & Rata - Rata Bobot Buah \\
\hline D. Tanpa Naungan & $81,55 \mathrm{a}$ \\
E. Naungan Plastik Transparan & $126,11 \mathrm{c}$ \\
F. Naungan Jerami Padi & $104,02 \mathrm{~b}$ \\
\hline BNT $5 \%=12,19$ &
\end{tabular}

Ket : Angka yang diikuti huruf yang sama tidak berbeda nyata pada uji BNT 5\%

Untuk pertumbuhan yang optimal tanaman paprika membutuhkan intensitas cahaya sedang di mana pada keadaan ini proses fotosintesis berlangsung optimal, respirasi normal sehingga fotosintat yang tersedia sebagian besar digunakan untuk pertumbuhan. Selain itu pada perlakuan menggunakan naungan, kehilangan air melalui transpirasi rendah sehingga tersedia air yang cukup untuk pembelahan dan pemanjangan sel yang akan menunjang pertumbuhan tinggi tanaman dan luas daun.

Fisher dan Goldsworthy (1996) mengemukakan bahwa ketersediaan air mempengaruhi pertumbuhan daun. Kekurangan air dapat menghambat pertumbuhan daun karena air mempengaruhi turgiditas sel penjaga. Apabila turgiditas sel menurun, stomata tertutup maka laju fotosintesis akan terhambat sehingga fotosintat yang dihasilkan berkurang. $\mathrm{Hal}$ ini akan mempengaruhi pembentukan sel-sel baru.

Hasil penelitian terhadap panjang buah, diameter buah, bobot buah dan jumlah buah menunjukkan bahwa perlakuan tanpa naungan menunjukkan hasil yang terendah dibanding naungan plastik transparan dan jerami padi. Hal ini menunjukkan bahwa tanaman paprika membutuhkan naungan untuk mendapatkan hasil yang optimal. Intensitas cahaya yang tinggi akan meningkatkan suhu daun akibatnya aktifitas enzim akan terganggu. Hal ini di antaranya dapat menyebabkan fotosintesis terhambat dan fotosintat yang dihsilkan rendah. Edmond, Andrews dan Halfacre (1975) mengemukakan bahwa intensitas cahaya di atas kisaran optimum akan mempengaruhi pertumbuhan dan hasil tanaman.

Hasil penelitian juga menunjukkan bahwa komponen hasil dari tanaman paprika yang diberi naungan plastik lebih baik dari yang diberi naungan jerami padi. Tanaman yang diberi naungan jerami padi, pada siang hari fotosintesisnya berlangsung optimal, respirasi normal, fotosintat yang dihasilkan tinggi. Akan tetapi pada malam hari naungan jerami padi menyebabkan kelembaban tinggi dan mempengaruhi suhu. Suhu menjadi rendah sehingga laju respirasi menurun akibatnya energi yang tersedia untuk pertumbuhan dan perkembangan buah berkurang sehingga pertumbuhan terhambat sekalipun fotosintat cukup tersedia. Sementara itu tanaman dengan perlakuan plastik transparan pada siang hari fotosintesisya optimal, respirasi normal. Pada malam hari, suhu optimal untuk proses respirasi sehingga energi yang dibutuhkan untuk pertumbuhan dan perkembangan buah cukup tersedia. Edmond et.al. (1975) menyatakan bahwa tanaman membutuhkan suhu optimum yang berbeda untuk pembentukan fotosintat pada siang hari dibandingkan dengan suhu optimum untuk pembentukan sel-sel baru 
yang berlangsung pada malam hari. Selanjutnya dikemukakan bahwa paprika, terong dan tomat membutuhkan kisaran agak tinggi pada malam hari untuk pertumbuhan dan perkembangan buah.

\section{KESIMPULAN}

Jenis naungan yang berbeda memberikan pengaruh yang berbeda terhadap pertumbuhan dan hasil paprika. Jenis naungan yang sesuai sehingga dapat memberikan hasil optimal bagi pertumbuhan dan hasil paprika yaitu naungan plastik trasparan.

\section{DAFTAR PUSTAKA}

Anonimous, 1990. Pengaruh Jenis Bahan Naungan Terhadap Hasil dan Kualitas Buah Cabai Paprika Kultivar Blue Star. Kumpulan klipping Paprika Pusat Informasi Pertanian. Jakarta.

Alberta, Dinar. 2004. Naungan Pada Tanaman Paprika. Badan Litbang Pertanian. Jakarta.

Cahyo, B. 2007. Cabai Paprika, Teknik Budidaya dan Analisis Usaha Tani. Kanisius. Yogyakarta.
Edmond, J. B. T., L. Andrews and R. G. Halfacre. 1975. Fundamental of Horticulture. 4rd ed. McGraws Hill Book New Delhi.

Fisher, N. M. dan P. R. Goldsworthy. 1996. Terjemahan. Gadjah Mada Univ. Press. Yogyakarta.

Hanolo, W., A. H. Bakrie dan H. Thalib. 1992. Laporan Hasil Penelitian Tanggapan Tanaman Paprika Terhadap Naungan dan ZPT Ergostim. Kementrian Ristek RI. Jakarta.

Muhanda, 2010. Budidaya Paprika di Bawah Naungan. www.scribd.com. Diakses 17 Nov. 2011.

Prihmantoro, H, Indriani, Y.H. 2000. Paprika Hidroponik dan Nonhidroponik. Penebar Swadaya. Jakarta

Williams, C.N.O. Uzo, W.T.H.Pregrine. 1993. Produksi Sayuran di Daerah Tropika. Terjemahan Soedharodjian Ronoprawiro. Gadjah Mada University. Jakarta. 